Рекомендована д. мед. наук, профр. О. М. Олещук

УДК 615.036.8

DOI 10.11603/2312-0967.2017.2.7910

\title{
ФАРМАКОЕПІДЕМІОЛОГІЧНИЙ АНАЛІЗ ТЕНДЕНЦІЙ ВИКОРИСТАННЯ БЕТА- ЛАКТАМНИХ АНТИБІОТИКІВ ДЛЯ ЛІКУВАННЯ ПНЕВМОНІЇ В РЕСПУБЛІЦІ ТАДЖИКИСТАН
}

\author{
(с) Л. В. Савченкова, М. Н. Саїдова, Н. С. Сангінова
}

\author{
Таджицький національний університет, Душанбе, Республіка Таджикистан \\ slv.05@gmail.com
}

\begin{abstract}
Мета роботи. Провести ретроспективний аналіз споживання $\beta$-лактамнихантибіотиків для лікування позалікарняної пневмонії в стаціонарах Республіки Таджикистан з використанням DDD-методології.

Матеріали і методи. Оцінювали споживання ß-лактамних антибіотиків згідно 3 індексом ATC/DDD BOO3 за 2011-2015 рр. В якості одиниці вимірювання використовувалося кількість грамів активної речовини з подальшим розрахунком показника загальної DDDs, DDDs/100 ліжко-днів та \% від загальної DDDs.

Результати й обговорення. Проведено ретроспективний аналіз споживання $\beta$-лактамних антибіотиків для лікування позалікарняної пневмонії в пульмонологічному відділенні багатопрофрільного стаціонару Республіки Таджикистан. Встановлено збільшення споживання ß-лактамних антибіотиків для лікування пневмонії за 20112015 рр. Виявлена динаміка зумовлена виключно за рахунок збільшення споживання антибактеріальних препаратів з групи цесралоспоринів, а саме цесралоспорину III покоління - цестриаксону. При цьому знизився інтерес в якості антибактеріальних препаратів для лікування позалікарняної пневмонії до антимікробних препаратів 3 групи пеніцилінів.

Висновки. Спостерігається поступове скорочення застосування для фрармакотерапії позалікарняної пневмонії препаратів пеніцилінового ряду (ампіцилін) і невиправдане зниження призначення одного з найбільш ефективних і безпечних антибіотиків - амоксициліну. Позитивним $€$ також зниження призначення цефалоспоринів першого покоління (цефразоліну). При цьому велика популярність цестриаксона становить потенційну небезпеку зростання резистентності до цього препарату і розвитку побічних реакцій, що вимагає більш ретельного контролю раціональності застосування даного антибіотика.
\end{abstract}

Ключові слова: позалікарняна пневмонія; антибіотики; фрармакоепідеміологічний аналіз.

Вступ. У структурі хвороб органів дихання багато років пневмонія займає лідируюче місце, на її частку припадає понад 60 \% всіх випадків інфекцій дихальних шляхів (ІДП) [1]. За даними М. H. Rozenbaum et al. [2] в Європі і Північній Америці позалікарняна пневмонія (ПП) зустрічається у 5-10 чоловік на 1 тис. дорослого населення. На думку А. Г. Чучаліна [1], якщо ці дані екстраполювати на Росію з населенням близько 140 млн жителів, можна вважати, що щорічно захворювання переносять більше 1,5 млн осіб дорослого населення країни, при цьому у 1 млн осіб діагноз пневмонії своєчасно не встановлено. Для Республіки Таджикистан (РТ) питання діагностики та ефективного лікування ПП також $€$ досить актуальним. Екстраполяція загальносвітових даних на РТ дозволяє стверджувати, що в республіці з населенням понад 8 млн жителів щорічно ПП переносять близько 1 млн мешканців. У окремих категорій населення показник захворюваності на ПП виявляється істотно вище. За даними ряду авторів [3-6] цей показник може досягати 30-40 \%, при цьому серед осіб молодого віку захворюваність на ПП становить 1-12 \%, серед старших вікових груп - 25-44 \%.

ПП є також однією з провідних причин смертності від інфекційних хвороб. За прогнозами ВООЗ, в XXI ст. летальність, внаслідок патології органів дихання, буде займати другий рядок в загальній структурі причин смерті. Смертність від ПП у осіб молодого і середнього віку без супутніх захворювань становить 1-3 \%, у пацієнтів старше 60 років при тяжкому перебігу пневмонії і наявності супутніх захворювань - 15-30 \% [2,7]. Високий рівень смертності зберігається і в РТ. Цьому сприяють кліматичні чинники, невисока доступність медичної допомоги, зумовлена значними відстанями від населених пунктів до центрів спеціалізованої медичної допомоги. Мають значення і недооцінка ступеня тяжкості ПП, несвоєчасне звернення до лікаря, відсутність повноцінного рентгенологічного та бактеріоскопічного дослідження при надходженні, пізня госпіталізація, неправильна оцінка тяжкості захворювання при надходженні $[3,8,9$, $10,11]$. Саме тому існуюча ситуація потребує деталь-

ISSN 2312-0967. Фармацевтичний часопис. 2017. № 2 
ної оцінки та аналізу проведеної фрармакотерапії та її модифрікації з урахуванням сучасних тенденцій світової антибіотикотерапії ПП.

Раціональний вибір антибіотика для терапії будьякої інфекції, в т. ч. ПП, передбачає врахування його активності щодо найбільш поширених патогенів, безпеки застосування, фрармакокінетичних характеристик, ризиків «паралельної шкоди» (побічного екологічного есректу антимікробної хіміотерапії у вигляді селекції полірезистентних штамів мікроорганізмів та викликана ними колонізація або інфекційний процес) [12]. Істотними, але менш значимими є зручність застосування і вартість АМП.

За наявними відомостями, частота пневмококів нечутливих до пеніциліну в Росії залишається стабільною і не перевищує 10 \%, при цьому в більшості випадків виявляються помірнорезистентні штами. Однак всі пеніцилінорезистентні пневмококи в Росії зберігають чутливість до амоксициліну, резистентність до цефтриаксону становить 0-2 \% [13]. Як відомо, з основних бактеріальних пневмотропних збудників пневмококи і гемофрільна паличка зберігають високу чутливість до амоксициліну; стасрілококи Moraxella catarrhalis, виділяючи лактамазу, зберігають чутливість до інгібіторзахищених пеніцилінів і цефралоспоринів [14].

Саме тому клінічні протоколи ведення хворих з ПП в якості стартової антибактеріальної терапії припускають використання саме $\beta$-лактамних антибіотиків макролідів (при наявності атипової фрлори). ß-лактамні антибіотики (пеніциліни, цефалоспорини, монобактами, карбапенеми) характеризуються наявністю в їх хімічній структурі $\beta$-лактамного кільця, яке зумовлює однаковий механізм дії та бактерицидний ефект. Унікальність цього класу антибіотиків полягає в тому, що відносно чутливих до них штамів їм немає рівних за силою антимікробної дії. Резистентність пневмококів досягається шляхом підвищення дози. На сьогодні немає даних про наявність клінічно значущої непереборної стійкості цього збудника до пеніцилінів і цефалоспоринів [15]. Для подолання стійкості, зумовленої продукцією $\beta$-лактамаз, створен захищені інгібітором $\beta$-лактамаз комбіновані препарати, що дозволило розширити спектр дії пеніцилінів не тільки проти грампозитивних коків, але і відносно більшості грамнегативних бактерій і анаеробів [16]. Безпека $\beta$-лактамних антибіотиків перевірена тривалим досвідом їх застосування. Саме ці незаперечні переваги препаратів даного класу стали основою їх популярністі. В РТ дослідження споживання антибактеріальних препаратів, в т. ч. $\beta$-лактамних антибіотиків з використанням уніфрікованих міжнародних показників одиничні і не систематизовані.

Мета роботи. Провести ретроспективний аналіз споживання $\beta$-лактамних антибіотиків для лікування ПП в стаціонарах Республіки Таджикистан з використанням DDD-методології.
Методи дослідження. Дослідження проводилося на базі пульмонологічного відділення Согдігської обласної клінічної лікарні (г. Худжанд, Республіка Таджикистан). Здійснено ретроспективний описовий аналіз лікарських призначень при фрармакотерапії пацієнтів з ПП, що перебували на лікуванні в даному відділенні. Дослідження проводилося в динаміці протягом 2011-2015 рр. Оцінювали споживання ß-лактамних антибіотиків для лікування ПП згідно 3 індексом ATC/DDD BOО3 [17]. В якості одиниці вимірювання використовували кількість грамів активної речовини з подальшим розрахунком показника загальної DDDs, DDDs/100 ліжко-днів та \% від загальної DDDs. Для обліку результатів дослідження, розрахунків описової статистики, побудови діаграм використовували програмні ресурси пакета Microsoft Office Excel, 2007.

Результати й обговорення. Проведений ретроспективний аналіз споживання АМП в пульмонологічному відділенні багатопрофрільного стаціонару для лікування ПП з використанням DDD-методології показав, що для антимікробної терапії даного захворювання використовуються АМП з різних груп та різним спектром антимікробної дії. При цьому інтенсивність споживання АМП в динаміці має чітку тенденцію до зниження, що мож н а розцінювати як позитивний фракт у боротьбі з необґрунтованим застосуванням АМП і як фрактор боротьби з антибіотикорезистентністю (рис. 1).

При цьому в більшості країн світу розроблено і впроваджено в клінічну практику стандарти надання медичної допомоги при різних захворюваннях, в т. ч. при ПП, згідно з якими лікування пневмонії різного ступеня тяжкості передбачає в якості стартової антибактеріальної терапії використання $\beta$-лактамних антибіотиків [18]. DDD-аналіз лікування ПП в стаціонарі показав, що $\beta$-лактамні антибіотики широко застосовуються в клінічній практиці для лікування пневмонії в РТ. Із даних рисунка 2 видно, що в структурі АМП, які використовують для лікування пневмонії, на тлі загального зниження кількості спожитих DDDs AMП, частка $\beta$-лактамних антибіотиків має чітку тенденцію до збільшення.

Так, якщо в 2011 р. загальна DDDs для препаратів цієї групи становила 353,5 DDDs або 32,18\% від загальної DDDs, то в 2015 р. аналізований показник становив 668,5 DDDs або 76,61\% від загальної DDDs. Ці дані були підтверджені при аналізі основного показника споживання ЛЗ в стаціонарі - DDDs / 100 ліжко-днів. Як показав частотний аналіз використання $\beta$-лактамних антибіотиків для лікування ПП, спожита DDDs для стартової антибактеріальної терапії пневмонії в 2011 р. склала - 3,68 DDDs, тоді як в 2015 р. цей показник збільшився майже в 1,9 раза і склав 6,96 DDDs (рис. 3).

Отримані дані свідчать про зміну підходів до стартової антибактеріальної терапії ПП з переходом до

ISSN 2312-0967. Pharmaceutical review. 2017. № 2 


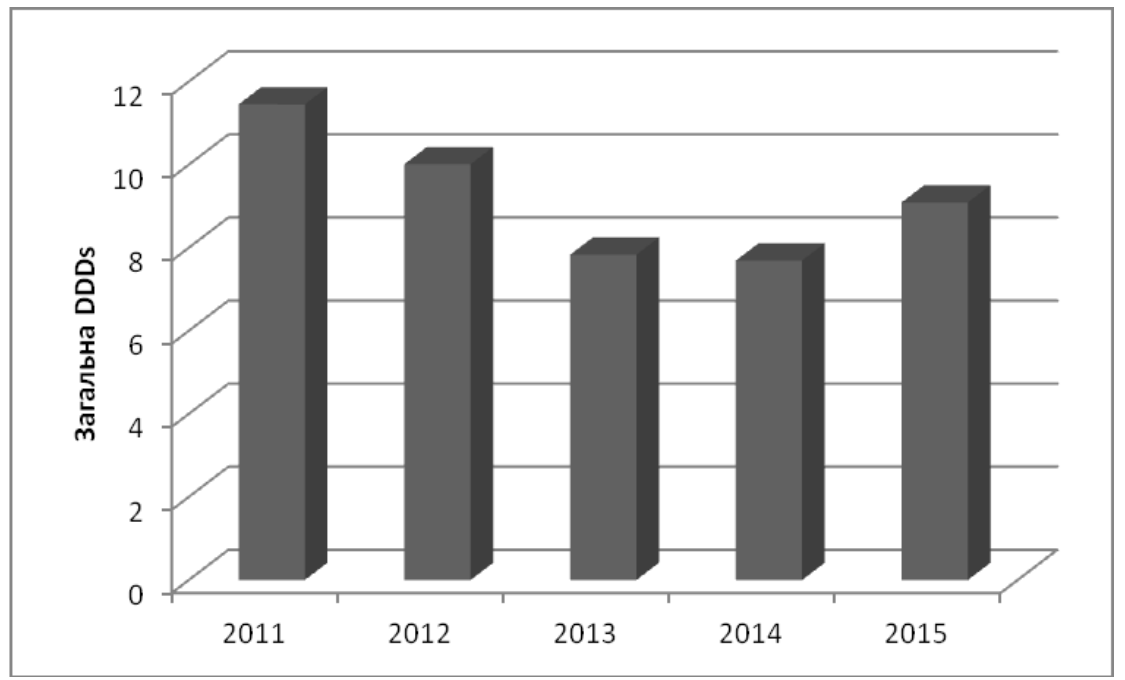

Рис. 1. Динаміка споживання АМП для лікування пневмонії в пульмонологічному відділенні багатопрофільного стаціонару (загальна DDDs).

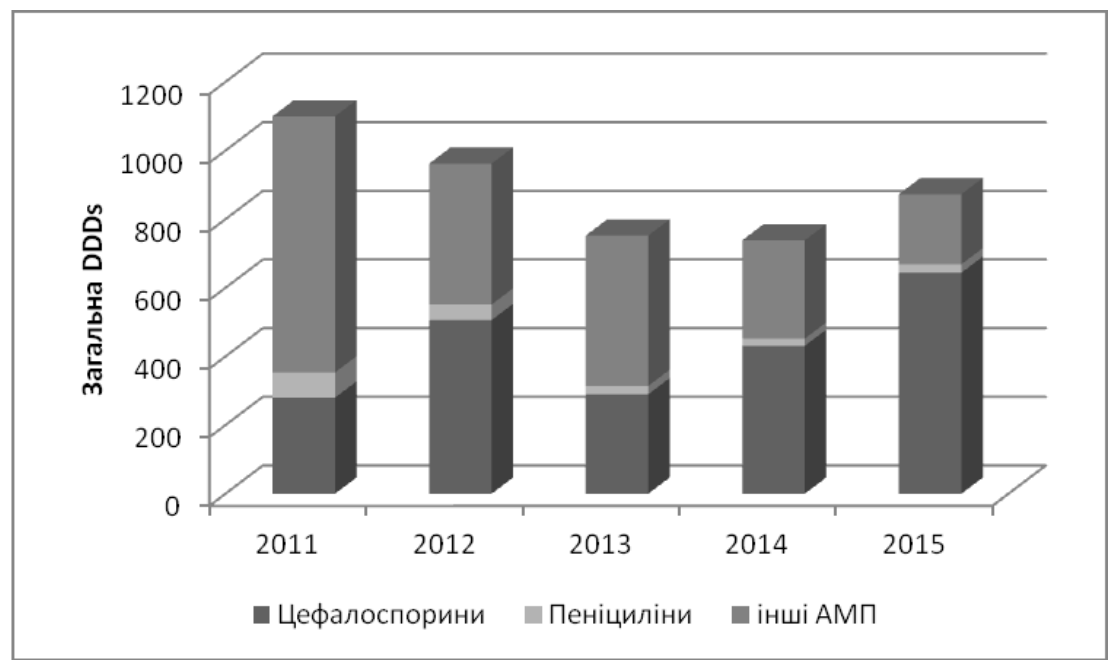

Рис. 2. Динаміка споживання ß-лактамних антибіотиків для лікування пневмонії в пульмонологічному відділенні багатопрофрільного стаціонару (загальна DDDs).

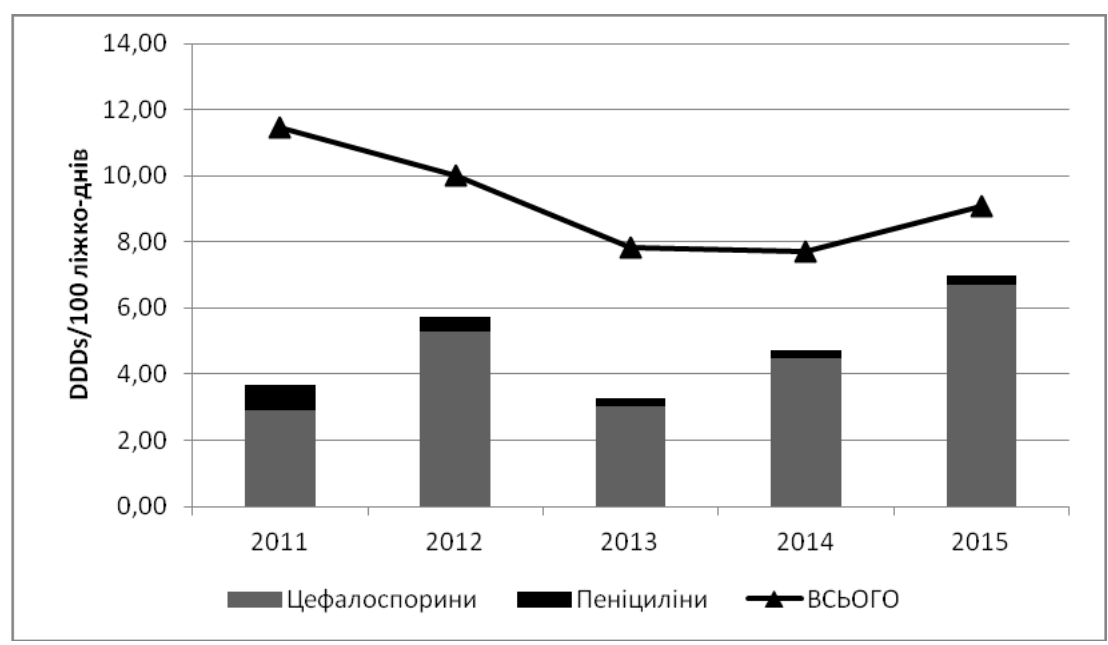

Рис. 3. Споживання ß-лактамних антибіотиків для лікування пневмонії в пульмонологічному відділенні багатопрофрільного стаціонару (DDDs/100 ліжко-днів).

ISSN 2312-0967. Фармацевтичний часопис. 2017. № 2 
загальносвітових стандартів надання медичної, в т. ч. антибактеріальної допомоги при лікуванні пневмонії, а саме використання для стартової антибактеріальної терапії $\beta$-лактамних антибіотиків: пеніцилінів і цесралоспоринів.

Подальший частотний аналіз застосування АМП для лікування ПП в багатопрофрільному стаціонарі РТ в динаміці показав, що найбільш затребуваними препаратами 3 групи ß-лактамних антибіотиків були цефалоспорини, частка яких серед $\beta$-лактамних антибіотиків становить від 79,21\% у 2011 р. до 96,34 \% в 2015 р. Іншими словами, для стартової антибактеріальної терапії ПП в більшості випадків використовують АМП з групи цефралоспоринів (рис. 4).

Відомо, що цефалоспорини є високоефективними і безпечними препаратами при лікуванні різних бактеріальних іноеекцій та препаратами вибору при ПП середнього та тяжкого ступеня. Незважаючи на тривале застосування і зниження до них чутливості деяких мікроорганізмів, ЦС, особливо препарати III і IV поколінь зберігають на даний час важливе значення в лікуванні інфекцій в стаціонарі. Як показав подальший аналіз, серед ЦС в пульмонологічному відділенні для лікування ПП використовували як препарати I покоління (цефазолін), так і АМП III-IV поколінь (цесртриаксон, цесртазидим, цесрепім).

Однак в більшості випадків ПП стартова антибактеріальна терапія включала ЦС III покоління - цефртриаксон, загальна DDDs якого становила 266 DDDs в 2011 р. (загальна DDDs всіх ЦС - 280 DDDs) і 637 DDDs в 2015 рр. (загальна DDDs всіх ЦС - 644 DDDs), що в 2,4 раза більше ніж у 2011 р. (рис. 5). 3 даних рисунка 5 видно, що частка спожитих доз інших представників групи ЦС становила лише 14 DDDs в 2011 р. і 7 DDDs в 2015 р.

Отримані дані підтверджено при аналізі такого показника споживання АМП в стаціонарі, як DDDs/100 ліжко-днів. 3 даних рисунка 6 видно, що за аналізований період цей показник для цефтриаксона збільшився в 2,4 раза і в 2015 р. склав 6,64 DDDs/100 ліжко-днів. При цьому такі АМП з групи ЦС, як цефазолін і цестазидим у 2015 р. вже не використовува-

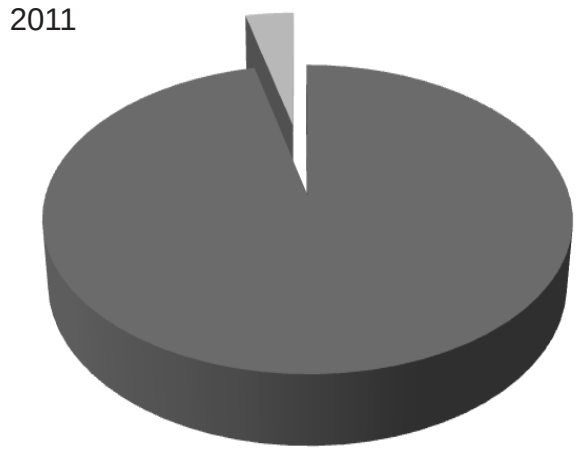

口 Цефалоспорини Пеніциліни
2015

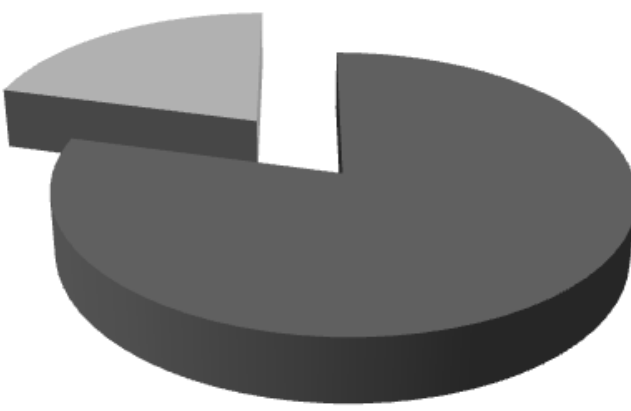

口 Цефалоспорини Пеніциліни

Рис. 4. Частка пеніцилінів та цефалоспоринів, що використовуються для лікування пневмонії в пульмонологічному відділенні багатопрофрільного стаціонару (\%).

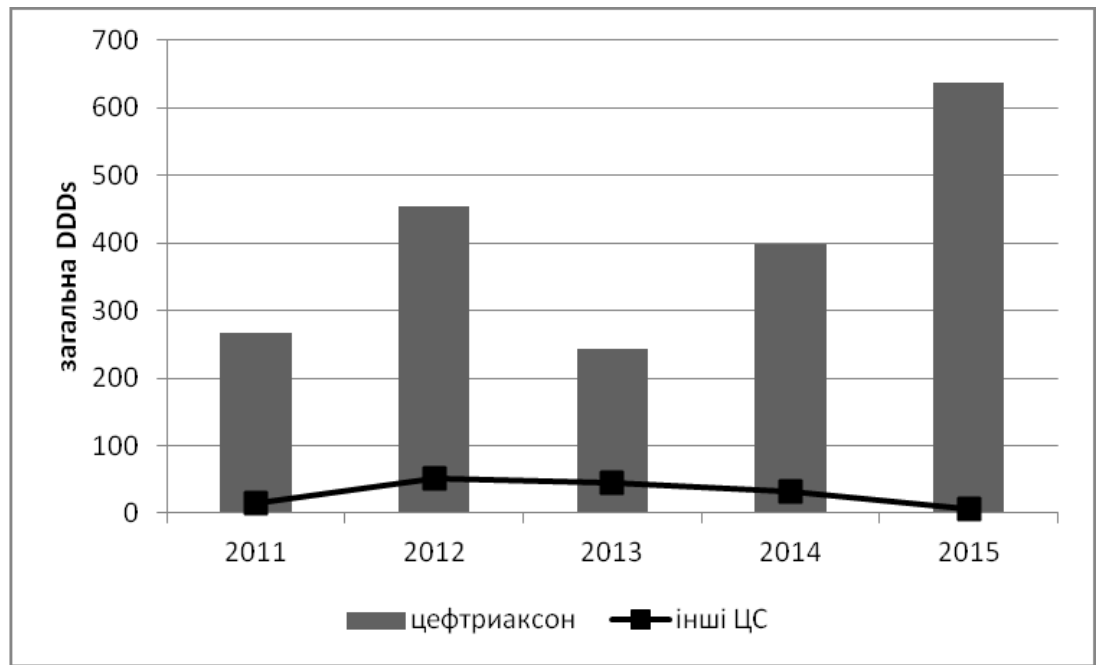

Рис. 5. Динаміка споживання окремих препаратів з групи цесралоспоринів для лікування пневмонії (загальна DDDs).

ISSN 2312-0967. Pharmaceutical review. 2017. № 2 
лися зовсім. Спостерігали поодинокі випадки споживання ЦС IV покоління - цефепіму, DDDs/100 ліжкоднів якого склало 0,07-0,15 DDDs за 2014-2015 pp.

3 наведених даних видно, що за аналізовані 5 років структура АМП з групи ЦС, використовуваних для лікування ПП, істотно змінилася зі зменшенням споживання ЦС І покоління і переходом на терапію ЦС III-IV поколінь.
При цьому споживання АМП з групи пеніцилінів за аналізований період суттєво зменшилося. Так, з даних рисунка 7 видно, що для лікування ПП в 2011-2015 pp. використовували лише ампіцилін і амоксицилін, загальна DDDs яких за 5 років зменшилася майже в 3 рази і в 2015 р. склала лише 24,5 DDDs. При цьому мало місце зниження попиту як на ампіцилін (спожито 42 DDDs в 2011 р. і 14 DDDs в 2015 р.), так і на амоксицилін (31,5 DDDs в 2011 р. і 10,5 DDDs в 2015 р.).

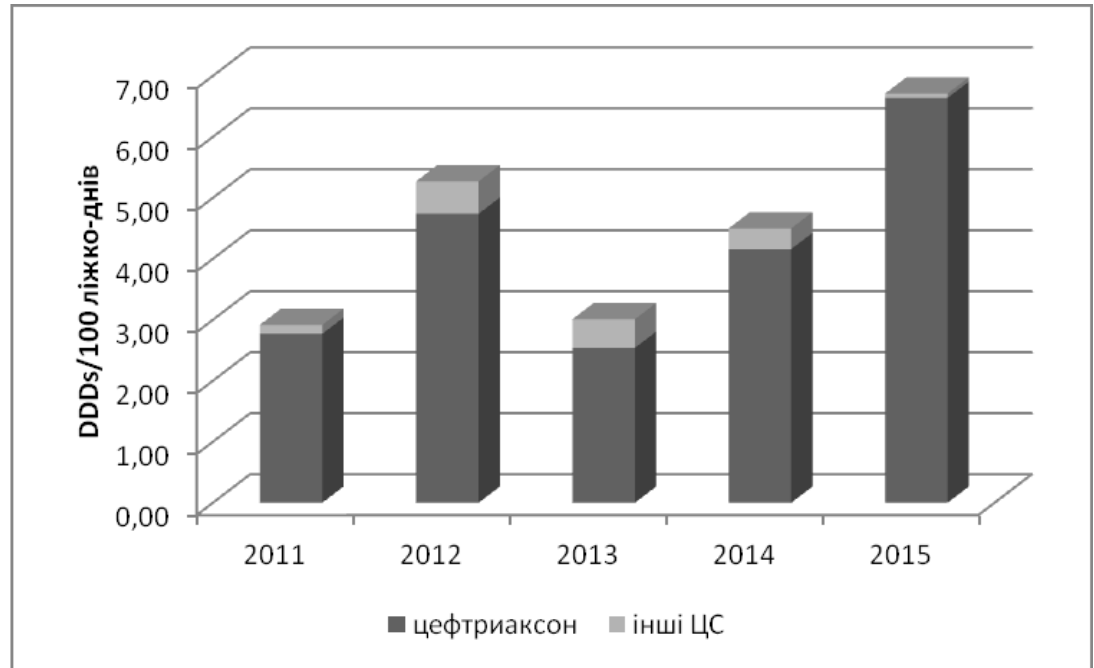

Рис. 6. Динаміка споживання окремих препаратів з групи цесралоспоринів для лікування пневмонії (DDDs/100 ліжко-днів).

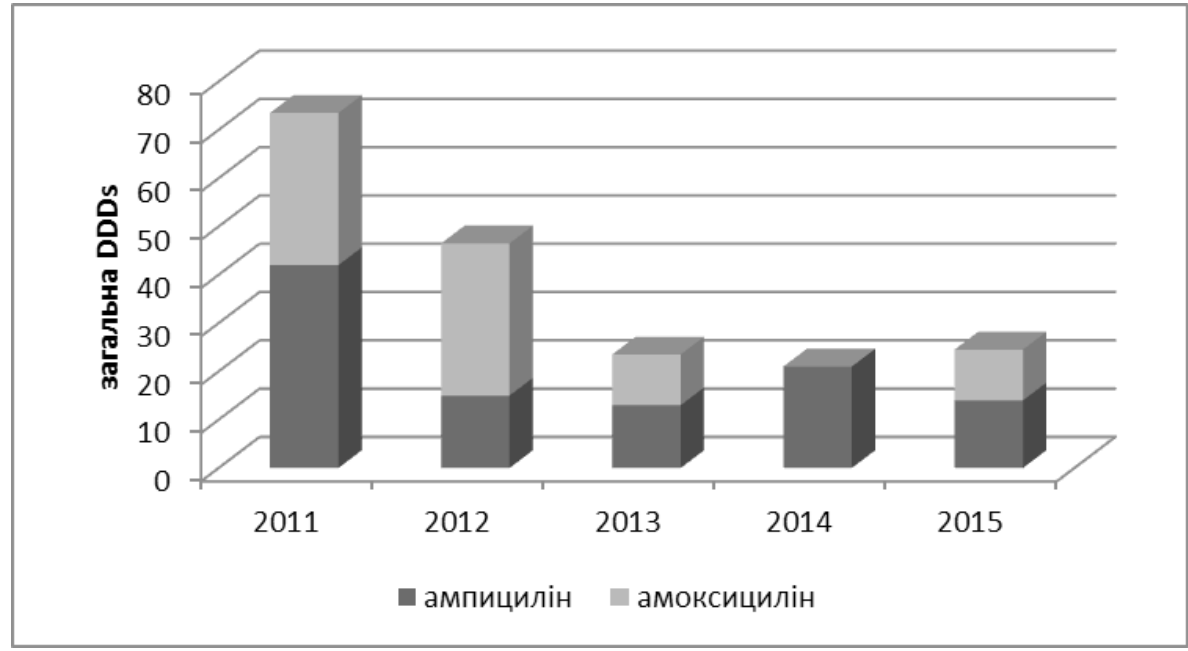

Рис. 7. Динаміка споживання окремих препаратів з групи пеніцилінів для лікування пневмонії (загальна DDDs).

Встановлено, що DDDs/100 ліжко-днів для ампіциліну за аналізований період знизилося в 2,9 раза, а для амоксициліну - в 3 рази (рис. 8), складаючи лише 0,11-0,15 DDDs.

Проведений аналіз і отримані дані свідчать, що АМП з групи пеніцилінів рідко використовують для лікування ПП в стаціонарі, при цьому є чітка тенденція до подальшого зниження інтересу до препаратів цієї групи як стартової антибактеріальної терапії ПП.
Висновок. Проведеними дослідженнями встановлено, що ß-лактамні антибіотики, які тривало застосовуються для лікування інфекційних захворювань різного генезу, як і раніше займають лідируючі позиції в лікуванні ПП. Проведений ретроспективний аналіз споживання $\beta$-лактамних антибіотиків для лікування ПП в пульмонологічному відділенні багатопрофрільного стаціонару РТ показав, що збільшення споживання препаратів цієї групи за аналізовані 5 років від-

ISSN 2312-0967. Фармацевтичний часопис. 2017. № 2 


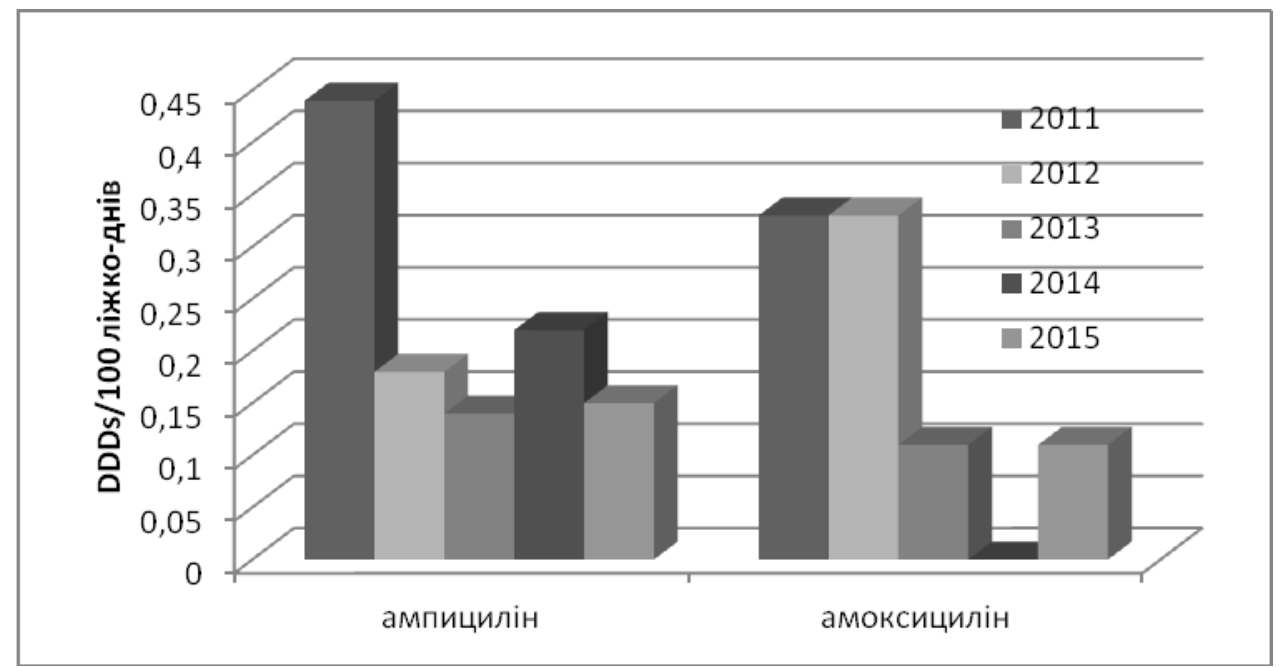

Рис. 8. Динаміка споживання окремих препаратів з групи пеніцилінів для лікування пневмонії (DDDs / 100 ліжко-днів).

булося виключно за рахунок АМП з групи цефалоспоринів, а саме ЦС III покоління - цефртриаксона. У схемах лікування ПП в останні роки не використовували ЦС I покоління - цефазолін. При цьому також знизився інтерес до АМП з групи пеніцилінів, що не можна вважати раціональним з точки зору відомої природної чутливості основних збудників ПП до АМП.

Певною мірою динаміка споживання пеніцилінів та цефралоспоринів в РТ відображає позитивні тенденції. Спостерігається поступове скорочення застосування ряду препаратів пеніцилінового ряду (ампіцилін) і невиправдане зниження споживання одного 3 найбільш ефективних і безпечних антибіотиків для лікування ПП - амоксициліну. Позитивним $€$ також зниження споживання цефалоспоринів першого покоління (цефразоліну). При цьому велика популярність цефтриаксона становить потенційну небезпеку зростання резистентності до цього препарату і розвитку побічних реакцій, що вимагає більш ретельного контролю раціональності застосування даного антибіотика.

Отримані дані можуть бути використані в освітніх програмах для лікарів з раціональної антимікробної терапії ПП в стаціонарі.

\title{
ФАРМАКОЭПИДЕМИОЛОГИЧЕСКИЙ АНАЛИЗ ТЕНДЕНЦИЙ ПРИМЕНЕНИЯ БЕТА-ЛАКТАМНЫХ АНТИБИОТИКОВ ДЛЯ ЛЕЧЕНИЯ ВНЕБОЛЬНИЧНОЙ ПНЕВМОНИИ В РЕСПУБЛИКЕ ТАДЖИКИСТАН
}

\author{
Л. В. Савченкова, М. Н. Саидова, Н. С. Сангинова
}

Таджикский национальный университет, Душанбе, Республика Таджикистан

slv.05@gmail.com

Цель работы. Провести ретроспективный анализ потребления $\beta$-лактамных антибиотиков для лечения внебольничной пневмонии в стационарах Республики Таджикистан с использованием DDD-методологии.

Материалы и методы. Оценивали потребление ß-лактамных антибиотиков согласно индексу ATC / DDD BO3 по 2011-2015 гг. В качестве единицы измерения использовалось количество граммов активного вещества с последующим расчетом показателя общей DDDs, DDD /100 койко-дней и \% от общего DDDs.

Результаты и обсуждение. Проведен ретроспективный анализ потребления ß-лактамных антибиотиков для лечения внебольничной пневмонии в пульмонологическом отделении многопрофильного стационара Республики Таджикистан. Установленоувеличениепотребления ß-лактамныхантибиотиков длялеченияпневмонииза2011-2015гг. Обнаруженадинамика обусловлена исключительно за счет увеличения потребления антибактериальных препаратов из группы цефралоспоринов, а именно цефралоспорина III поколения - цефтриаксона. При этом снизился интерес в качестве антибактериальных препаратов для лечения внебольничной пневмонии к антимикробным препаратам из группы пенициллинов.

Выводы. Наблюдается постепенное сокращение применения для фрармакотерапии внебольничной пневмонии препаратов пенициллинового ряда (ампициллин) и неоправданное снижение потребления одного из самых эффрективных и безопасных антибиотиков - амоксициллина. Позитивным является снижение потребления

ISSN 2312-0967. Pharmaceutical review. 2017. № 2 
цефалоспоринов первого поколения (цефазолина). При этом большая популярность цестриаксона, несет в себе потенциальную опасность роста резистентности к этому препарату и развития побочных реакций, что требует более тщательного контроля рациональности применения данного антибиотика.

Ключевые слова: внебольничная пневмония; антибиотики; фармакоэпидемиологический анализ.

\title{
PHARMACOEPIDEMIOLOGICAL ANALYSIS OF TRENDS IN THE CONSUMPTION OF BETA-LACTAM ANTIBIOTICS FOR THE TREATMENT OF PNEUMONIA IN THE REPUBLIC OF TAJIKISTAN
}

\author{
L. V. Savchenkova, M. N. Saidova, N. S. Sanginova \\ Tajik National University, Dushanbe, Republic of Tajikistan \\ slv.05@gmail.com
}

The aim of the work. Conducting a retrospective analysis of the consumption of $\beta$-lactam antibiotics for the treatment of community-acquired pneumonia in hospitals in the Republic of Tajikistan using the DDD methodology.

Materials and Methods. The consumption of $\beta$-lactam antibiotics was estimated according to the WHO ATC/DDD index for 2011-2015. The unit of measurement used was the number of grams of the active substance, followed by calculation of the total DDDs, DDD / 100 bed-days and \% of total DDDs.

Results and Discussion. A retrospective analysis of the consumption of $\beta$-lactam antibiotics for the treatment of communityacquired pneumonia in the Pulmonology Department of the Multidisciplinary Hospital of the Republic of Tajikistan was conducted. An increase in the consumption of $\beta$-lactam antibiotics for the treatment of pneumonia in 2011-2015 was established. The dynamics was determined exclusively due to an increase in the consumption of antibacterial drugs from the group of cephalosporins, namely cephalosporin of the third generation - ceftriaxone. At the same time interest in the quality of antibacterial drugs for the treatment of community-acquired pneumonia to antimicrobial drugs from the penicillin group decreased.

Conclusions. There is a gradual reduction in the use of penicillin preparations (ampicillin) for pharmacotherapy of community-acquired pneumonia and an unjustified reduction in consumption of one of the most effective and safe antibiotics - amoxicillin. There is a decrease in the consumption of first-generation cephalosporins (cefazolin). In this case, the great popularity of ceftriaxone, carries the potential danger of increasing resistance to this drug and the development of adverse reactions, which requires more careful monitoring of the rationality of the use of this antibiotic.

Key words: community-acquired pneumonia; antibiotics; pharmacoepidemiological analysis.

\section{Список літератури}

1. Чучалин А. Г. Пневмония: актуальная проблема медицины XXI века // Пульмонология. - 2015. - Т. 25, № 2. - C. 133-142.

2. Rozenbaum M. H. The role of Streptococcus pneumoniae in community-acquired pneumonia among adults in Europe: a metaanalysis / M. H. Rozenbaum // Eur. J. Clin. Microbiol. Infect. Dis. - 2013. - Vol. 32, №3. - P.305-316.

3. Круглякова Л. В. Особенности течения и исходы внебольничных пневмоний по данным Благовещенской городской клинической больницы (2009-2014) / Л. В. Круглякова, С. В. Нарышкина // Бюл. фризиол. и патол. дыхания. - 2015. - Вып. 57. - С. 42-48.

4. Писаренко Н. К. Смертность от пневмонии лиц трудоспособного возраста в республике Молдова / Н. К. Писаренко, С. В. Писаренко // XXV Национальный конгресс по болезням органов дыхания: сб. трудов. M., 2015. - C. 350-351.

5. Летальные исходы от внебольничной пневмонии в Ивановской области за 2014 г. / Н. А. Суховей, Н. В. Шутова, М. Г. Омельяненко [и др.] // XXV Национальный конгресс по болезням органов дыхания: сб. трудов. - М., 2015. - С. 183.
6. Шаймуратов Р. И. Оценка влияния сопутствующих заболеваний на исход внебольничной пневмонии // XXV Национальный конгресс по болезням органов дыхания: сб. трудов. - М., 2015. - С. 163.

7. Иванова Г. В. Заболеваемость и смертность населения трудоспособного возраста России по причине болезней органов дыхания в 2010-2012 гг. / Г. В. Иванова, Т. Н. Биличенко, А. Г. Чучалин // Пульмонология. -2015. - T. 25, № 3. - С. 291-297.

8. Клиническая характеристика внебольничных пневмоний у военнослужащих, вакцинированных пневмококковой вакциной / Т. Г. Шаповалова, И. М. Борисов, П. Е. Крайнюков [и др.] // Пульмонология. - 2012. - № 2. - C. 78-81.

9. Одинаев Ф. И. Факторы риска развития внебольничной пневмонии в Республике Таджикистан // Здравоохранение Таджикистана. - 2015. - № 1. C. 89-96.

10. БолотоваЕ. В. Анализ дефектов оказания лечебнодиагностической помощи больным, умершим от внебольничной пневмонии в Красноярском крае за 2014 г. / Е. В. Болотова, Л.В.Шульженко, В.А.Порханов

ISSN 2312-0967. Фармацевтичний часопис. 2017. № 2 
// Пульмонология. - 2015. - Т. 25, № 3. - С. 298-302.

11. Круглякова Л. В. Динамика исходов внебольничной пневмонии в свете соблюдения рекомендаций Российского респираторного общества/Л. В. Круглякова, С. В. Нарышкина, Г. С. Налимова // Материалы II съезда врачей-пульмонологов Сибири и Дальнего Востока. Благовещенск, 2007. - С. 72-74.

12. Внебольничная пневмония у пациентов пожилого и старческого возраста / А. А. Бобылев, С. А. Рачина, С. Н. Авдеев [и др.] // Пульмонология. -2015. Т. 25, № 3. - C. 261-276.

13. чучалин А. Г. Внебольничная пневмония у взрослых: практические рекомендации по диагностике, лечению и профилактике: пособие для врачей / А. Г. Чучалин. - М., 2010. - 106 c.

14. Таточенко В. К. Болезни органов дыхания у детей: практическое руководство / В. К. Таточенко. - М. : Педиатр, 2012. - С. 82-85.

15. Guidelines for the management of adult lower respiratory tract infections. ERS Task Force Report in collaboration with ESCMID // Infectious Diseases. - 2011. - Vol. 17 (Suppl. 6). - P. 124.

16. Практическое руководство по антиинфекционной химиотерапии / под ред. Л. С. Страчунского, Ю. Б. Белоусова, С. Н. Козлова. Смоленск : МАК-МАХ, 2007. - 464 C.

17. About ATC/DDD system. Режим доступа: http://www. WHOCC.NO/ATCDDD (дата обращения 22.01.2013).

18. Алгоритмы диагностики и протоколы оказания медицинской помощи при пневмонии: методические рекомендации для врачей / И. В. Демко, С. В. Чубарова, Н. В. Гордеева [и др.]. - Москва, 2015. - 51 с.

\section{References}

1. Chuchalin AG. [Pneumonia: an urgent problem of medicine of the XXI century]. Pulmonologiya. 2015; 25(2): 13342. Russian.

2. Rozenbaum MH. The role of Streptococcus pneumoniae in community-acquired pneumonia among adults in Europe: a metanalysis. Eur. J. Clin. Microbiol. Infect. Dis. 2013; 32(3): 305-16.

3. Kruglyakova LV, Naryshkina SV. [Features of the course and outcomes of out-of-hospital pneumonia according to the Blagoveshchensk City Clinical Hospital (2009-2014)]. Byul. fiziol. i patol. dykhaniya. 2015; 57: 42-8. Russian.

4. Pisarenko N.K, Pisarenko SV. [Mortality from pneumonia of persons of working age in the Republic of Moldova]. // XXV Natsionalnyy kongress po boleznyam organov dykhaniya: sb. trudov. 2015; 350-1. Russian.

5. Sukhovey NA, Shutova NV, \& Omelyanenko MG. [Lethal outcomes from community-acquired pneumonia in the Ivanovo region for 2014]. XXV Natsionalnyy kongress po boleznyam organov dykhaniya: sb. trudov. 2015;.183. Russian.

6. Shaymuratov RI. [Assessment of the impact of concomitant diseases on the outcome of community-acquired pneumonia]. XXV Natsionalnyy kongress po boleznyam organov dykhaniya: sb. trudov. 2015; 163. Russian.

7. Ivanova GV, Bilichenko TN, Chuchalin AG. [Morbidity and mortality of the working-age population of Russia due to respiratory diseases in 2010-2012]. Pulmonologiya. 2015; 25(3) 291-7. Russian.

8. Shapovalova TG, Borisov IM, Kraynyukov PYe. [Clinical characteristics of community-acquired pneumonia in military personnel vaccinated with pneumococcal vaccine]. Pulmonologiya. 2012; 2: 78-81. Russian.

9. Odinayev FI. [Risk factors for the development of community-acquired pneumonia in the Republic of Tajikistan]. Zdravookhraneniye Tadzhikistana.2015; 1: 89-96. Russian.

10. Bolotova YeV, Shulzhenko LV, Porkhanov VA. [Analysis of defects in the provision of medical and diagnostic care to patients who died of community-acquired pneumonia in the Krasnoyarsk Territory in 2014]. Pulmonologiya. 2015; 25(3):298-302. Russian.

11. Kruglyakova LV, Naryshkina SV, Nalimova GS. [The dynamics of out-of-hospital pneumonia outcomes in the light of the recommendations of the Russian respiratory society]. Materialy II syezda vrachey-pulmonologov Sibiri i Dalnego Vostoka. 2007: 72-4. Russian.

12. Bobylev AA, Rachina SA, Avdeyev SN. [Communityacquired pneumonia in elderly and senile patients]. Pulmonologiya. 2015; 25(3):261-76. Russian.

13. Chuchalin AG. Community-acquired pneumonia in adults: practical recommendations for diagnosis, treatment and prevention: a manual for doctors. [Внебольничная пневмония у взрослых: практические рекомендации по диагностике, лечению и профилактике: пособие для врачей] Moscow; 2010. Russian.

14. Tatochenko VK. [Diseases of the respiratory system in children: practical guidance]. Pediatr. 2012: 82-5. Russian. 15. Guidelines for the management of adult lower respiratory tract infections. ERS Task Force Report in collaboration with ESCMID. Infectious Diseases. 2011;17: 124.

16. Strachunskiy LS, Belousov YuB, Kozlov SN. Practical guidance on anti-infectious chemotherapy. [Практическое руководство по антиинфекционной химиотерапии] Smolensk. IACMAC; 2007: 464. Russian.

17. About ATC/DDD system. Access mode: http: // www. WHOCC.NO/ATCDDD (circulation date 22.01.2013).

18. Demko IV, Chubarova SV, Gordeyeva NV. Diagnostic algorithms and protocols for the provision of medical care for pneumonia. [Алгоритмы диагностики и протоколы оказания медицинской помощи при пневмонии] 2015: 51. Russian. 